\title{
Myrmecophily on Leucas chinensis (Lamiaceae)
}

\author{
Prasad. E. R* \& Sunojkumar P. \\ Department of Botany, University of Calicut, Malappuram, Kerala-673 635.
}

\begin{abstract}
Ants were identified as the most common and abundant floral visitor. The observed behaviour indicated that ants may contribute to pollination on Leucas chinensis. Detailed studies were carried out on the Phenology, floral biology, pollination and breeding system of L. chinensis. The main flowering season between August-December and occasional flowering found other seasons also. The flower is typical Lamiacean bilabiate. The inflorescence is verticillaster. Inflorescence initials are generally activated in the leaf axils. Anther dehiscence mode is longitudinal. The pollen grains were spherical and tricolpate. The size of the pollen is $26.90 \pm 3.0$ and $85 \%$ of pollen viable at 12am. The stigma is dry type and receptive between 12am-1.00pm. The fruit is nutlet and seed ovule ratio is 4:4. In breeding experiment we found that apomixis not present in this Leucas member maximum fruit set occur in the open pollination and xenogamy (95\% and $90 \%$ respectively). The flower offer nectar and pollen as rewards for floral visitors. Flowers were visited by several insects and butterflies. The potential pollinators were Apis cerana, Amegilla sp., Ceratina sp. and Componotus parius were pollinators. The pollen grains were stuck on the ant body while visiting flower we directly documented ants movement on flower.
\end{abstract}

\section{Introduction}

The intricate methods by which cross pollination is accomplished in the Lamiaceae reflect a long history of co-evolution between plants and pollinators. In spectrum of pollination systems includes entomophily and ornithophily but no records in bat pollination or wind pollination in Lamiaceae (Huck, 1992). The main pollination systems of the family includes nototriby and sternotriby. Bees, by far, most commonly observed pollinators of this family. The family is known for volatile oil glands that may stimulate the responses from pollinators (Beker et al., 1989). Previous studies on Leucas species ( Shrihail K. Kulloli et al., 2011) confirms that ants were very common flower visitor.

Leucas chinensis Straggling herb, perennial basal stem and root stock, branch long up to $1 \mathrm{~m}$ high. Quadrangular, not grooved dense. Inflorescence few flowered clusters in many axils, 3-7 cluster. Corolla white, $17 \mathrm{~mm}$ long; tube $8 \mathrm{~mm}$ long included calyx tube. Ovary locules $0.5 \mathrm{~mm}$ high, stigma bifid almost equal lobes.

\section{Materials and methods}

The plant was collected from Munnar(Idukki district). The plant were multiplied and grown in the Calicut university Botantical garden for detailed study.

\section{Floral biology}

Phenology is defined as the timing of biological events. Plants in the experimental plot were observed daily to study the flowering phenology; special attention was given to identify the flowering season, flower initiation, development, anthesis, anther dehiscence etc. The floral parts were studied by using hand lens and stereomicroscope (Leica CM, 1100). The measurements of the floral parts were taken with the help of a plastic scale.

The number of pollen grains per flower was calculated as suggested by Shivanna \& Rangaswami (1992). Pollen fertility was assessed by staining them in $1 \%$ acetocarmine. Pollen viability was estimated by tetrazolium test. Histochemical analysis were carried out in stigmas and pollen grains of Leucas chinensis to study the presence of primary metabolites like starch, protein and lipids. For histochemical analysis thin hand sections were taken. Stigma receptivity analyzed by $\alpha$ - naphthayl acetate. In this test excised stigma dipped in 2 drops of $\alpha$ - naphthyl acetate solution for 30 minutes, after that, the stigma washed with phosphate buffer and observe the changes.

\section{Pollination biology}

Continuous observations were made on the behavior of different floral visitors. The number of floral visitors, percentage of floral visit and stigma touch by insects were noted. Foraging period and foraging nature were observed. Frequency of visit calculated. After each visit stigma were observed by hand lens and confirmed the transfer of pollens by each visitors. The visitors were captured using hand net, killed using ethyl acetate or 
ethanol and observed under stereo microscope for pollen load on the body parts. Pollination systems such as apomixis, autogamy, geitonogamy and xenogamy and open pollination were tested.

\section{Result}

Leucas chinensis started flowering from August- December. Inflorescence initials are generally activated in the leaf axils. Flower opening in L. chinensis began around 4.00am and was completed around 5.00am. Anther dehiscence begans with a longitudinal slit appears on the anther lobes at $4.00 \mathrm{am}$ after opening the flower and the process was completed between 4.30-5.00am, this result in the release of the masses of pollen grains around 4.00am. Anthesis started between 4am-5am. Anther dehiscence occurs around 4.30am-5.00am.

The average duration taken from inflorescence initiation to opening of the first flower was 10 days The average duration taken from the opening of the first flower to the opening of the last flower was 3-4 weeks.

Pollen productivity of plants depends upon anther length, pollen grains and mode of anther dehiscence (Linskens 1992 \& Reddi, 1986). Floral analysis of the two species indicated that, the flower has didynamous stamen and are 4 in number. All the 4 stamens are free but are inserted close to each others on the dorsal side of the corolla tube. An anther contain 334 pollen grains. They ovaries are basically dimerous, but as each carpel is divided by a false wall, four rooms are formed, all containing one ovule which form 4 nutlets after fertilization. Hence the pollen ovule ratio is 1960:4. Stigma bifid, stigmatic surface was dry and stigma receptivity was high at $12 \mathrm{am}-1.00 \mathrm{pm}$.

\section{Pollen morphology}

Pollen grains were spherical, tricolpate, the equatorial outline is usually rounded triangular or circular. They average diameter of pollen grain is $26.55 \pm 3.0 \mu \mathrm{m}$.

\section{Pollen-Ovule Ratio}

Floral analysis of the two species indicated that, the flower has didynamous stamen and are 4 in number. An anther contain 334 pollen grains . They ovaries are basically dimerous, but as each carpel is divided by a false wall, four rooms are formed, all containing one ovule which form 4 nutlets often fertilization. Hence the pollen ovule ratio is 1960:4.

Table 1. FLORAL PHENOLOGY OF LEUCAS CHINENSIS

\begin{tabular}{ll}
\hline Flowering period & August-December \\
Inflorescence type & Verticillaster \\
Flower type & Regular, Bisexual \\
Flower colour & White \\
Odour & Absent \\
Nectar & Present \\
Anthesis time & $4-5 a m$ \\
Anther dehiscence time & $4.30-5$ am \\
Anther dehiscence mode & Longitudinal \\
Number of anthers per flower & 4 \\
Mean number of ovules per flower & 4 \\
Mean number of pollen per anther & 334 \\
Pollen ovule ratio & $1960: 4$ \\
Pollen shape & Spherical \\
Pollen type & Tricolpate \\
Pollen size & $26.55 \pm 3.0$ \\
Sigma type & Dry \\
Stigma receptivity & $12 a m-1.00 p m$ \\
Fruit type & Nutlet \\
Ovule seed ratio & $4: 4$ \\
\hline
\end{tabular}

Pollen viability

Pollen viability was tested by using tetrazolium solution. They test revealed that, only $10 \%$ and $20 \%$ of pollen grains were viable soon after anthesis $80 \%$ pollen grains were viable at $12 \mathrm{pm}$. At $12 \mathrm{pm}$ the pollen viability is also $80 \%$ and gradually decreases (Table 2). 
Table 2. POLLEN VIABILITY

\begin{tabular}{|l|l|l|}
\hline Sl. No & Time & $\begin{array}{l}\text { Leucas } \\
\text { chinensis }\end{array}$ \\
\hline 1 & $6.00 \mathrm{am}$ & $17.67 \pm 5.38$ \\
2 & $7.00 \mathrm{am}$ & $20.19 \pm 7.20$ \\
3 & $8.00 \mathrm{am}$ & $31.32 \pm 9.50$ \\
4 & $9.00 \mathrm{am}$ & $42.59 \pm 11.35$ \\
5 & $10.00 \mathrm{am}$ & $46.45 \pm 9.32$ \\
6 & $11.00 \mathrm{am}$ & $62.16 \pm 6.78$ \\
7 & $12.00 \mathrm{pm}$ & $80.97 \pm 3.31$ \\
8 & $1.00 \mathrm{pm}$ & $66.02 \pm 7.49$ \\
9 & $2.00 \mathrm{pm}$ & $46.59 \pm 12.66$ \\
10 & $3.00 \mathrm{pm}$ & $29.86 \pm 10.51$ \\
11 & $4.00 \mathrm{pm}$ & $14.71 \pm 4.94$ \\
12 & $5.00 \mathrm{pm}$ & $5.93 \pm 4.02$ \\
13 & $6.00 \mathrm{pm}$ & 0 \\
\hline
\end{tabular}

\section{Pollen fertility}

Pollen fertility was determined by using acetocarmine-glycerine stains. Acetocarmine-glycerine staining technique in L. chinensis revealed that $95 \%$ pollen grains were fertile at $11 \mathrm{pmIn}$, soon after dehiscence pollen grains show lesser fertility (Table. 3)

\section{Table 3. POLLEN FERTILITY}

\begin{tabular}{|l|l|l|}
\hline \multirow{2}{*}{$\begin{array}{l}\text { Sl. } \\
\text { No }\end{array}$} & Time & $\begin{array}{l}\text { Acetocarmine- } \\
\text { Glycerine Test }\end{array}$ \\
\cline { 3 - 3 } & & Leucas chinensis \\
\hline 1 & $6.00 \mathrm{am}$ & $71.16 \pm 9.85$ \\
2 & $7.00 \mathrm{am}$ & $78.79 \pm 6.09$ \\
3 & $8.00 \mathrm{am}$ & $80.48 \pm 3.41$ \\
4 & $9.00 \mathrm{am}$ & $85.07 \pm 3.34$ \\
5 & $10.00 \mathrm{am}$ & $89.48 \pm 4.99$ \\
6 & $11.00 \mathrm{am}$ & $95.38 \pm 1.52$ \\
7 & $12.00 \mathrm{pm}$ & $90.35 \pm 0.1$ \\
8 & $1.00 \mathrm{pm}$ & $87.76 \pm 5.4$ \\
9 & $2.00 \mathrm{pm}$ & $85.34 \pm 2.1$ \\
10 & $3.00 \mathrm{pm}$ & $83.98 \pm 5.10$ \\
11 & $4.00 \mathrm{pm}$ & $82.35 \pm 7.52$ \\
12 & $5.00 \mathrm{pm}$ & $78.79 \pm 6.09$ \\
13 & $6.00 \mathrm{pm}$ & $66.02 \pm 7.49$ \\
\hline
\end{tabular}

\section{Stigma receptivity}

Receptivity of stigma was analysed by $\alpha$-Naphthyl acetate. If the stigma was more receptive, the stigma was stained in deep blue colour. In $L$. chinensis the stigma was more receptive at $11 \mathrm{am}-12 \mathrm{pm}$ receptivity is gradually decreases (Table. 4 ).

Table 4. STIGMA RECEPTIVITY OF FLOWER ON $\alpha$-NAPHTHALINE ACETATE

\begin{tabular}{|l|l|l|}
\hline \multirow{2}{*}{ Sl. No. } & \multirow{2}{*}{ Time } & Frequency of colour \\
\cline { 3 - 3 } & & Leucas chinensis \\
\hline 2 & $6-8.00 \mathrm{am}$ & Light bluish black \\
3 & $8-10.00 \mathrm{am}$ & Bluish black at the tip \\
4 & $10-12.00 \mathrm{am}$ & Dark bluish black \\
5 & $12-2.00 \mathrm{pm}$ & Dark blue at the tip \\
6 & $2-4.00 \mathrm{pm}$ & blue \\
\hline
\end{tabular}

\section{Breeding analysis}

In the open pollination in natural conditions resulted in $95 \%$ fruit set. Apomixis, Flower bud bagged by removing stamens and stigma resulted no fruit set. Autogamy was carried out around 20 flowers. Self pollination resulted in $85 \%$ fruit set. Manual pollinations using pollen from other flowers of the same plant 
resulted in $80 \%$ fruit set. Manual cross pollinations using pollen from flowers of different plant resulted in $90 \%$ fruit set.
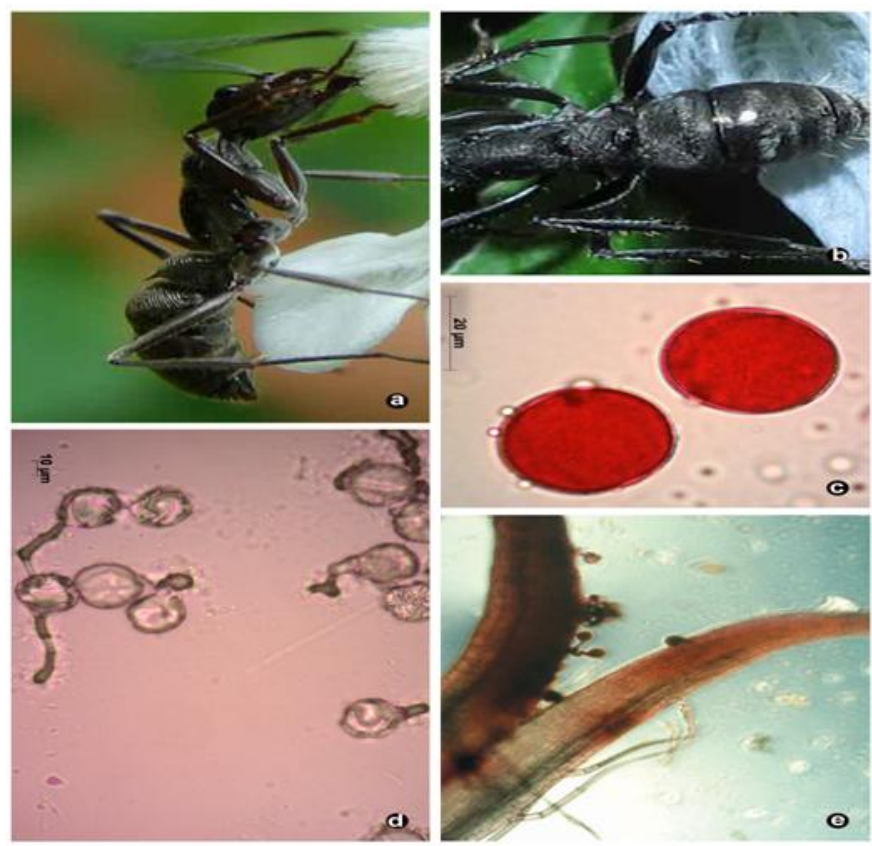

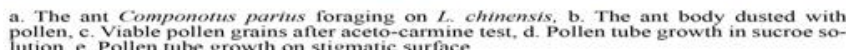

Table 5. Breeding system analysis.

\begin{tabular}{|l|l|l|l|l|}
\hline $\begin{array}{l}\text { Sl. } \\
\text { No. }\end{array}$ & $\begin{array}{l}\text { Breeding system } \\
\text { analysis }\end{array}$ & $\begin{array}{l}\text { No.of flowers } \\
\text { pollinated }\end{array}$ & $\begin{array}{l}\text { No.of flowers } \\
\text { fruit set }\end{array}$ & $\begin{array}{l}\text { Percentage of fruit } \\
\text { set }\end{array}$ \\
\hline & & & & \\
1 & Open pollination & 20 & 19 & 95 \\
2 & Apomixis & 20 & 0 & 0 \\
3 & Autogamy & 20 & 17 & 85 \\
4 & Geitonogamy & 20 & 16 & 80 \\
5 & Xenogamy & 20 & 18 & 90 \\
\hline
\end{tabular}

\section{Pollinators}

Initial studies on floral visitors were made from dawn to dusk for 30 min every hour, on the basis of which subsequent observation were confined to the time frame of $06.00 \mathrm{~h}$ to $17.00 \mathrm{~h}$. The number of floral visits made by an insect and time spent on each flower were recorded by using stop watch. Hyminopterans members were chief flower visitors. Apis cerana, Ceratina sp, and Apis florae were visiting flower regularly. The solitary bees like amegilla sp.was found throughout the day. The frequency of visits was high when the plants produce more flowers. The foraging activity of butterflies influenced by weather, the butterflies were active on sunny days less active in the cloudy days.

The arrangement of androecial characters is a major concern in the pollination biology. In the Leucas sp essential characters were arranged in the upper lip and insects landing on the lower lip insert proboscis in to corolla tube, while probing nectar insect back touching the anther lobe and big chance to pollen grains stuck on the insect body (nototriby).

\section{Ant behaviour on flower}

The present data confirm the original hypothesis that the ant pollinate L. chinensis. The ant Componotus parius was a regular visitor it collect pollen and nectar. It forages normally day times and direct photograph shown that pollen stuck on the ant's body. The body of this ant suitable to pollen adhering. We collected pollen grains from captured ants. The ant visited more than 80 flower per day and it spent several seconds each flower. It collects pollen grains by using its mouth parts and hands. They also touched stigma while probing nectar and pollen collection. They have to reach the flowers by crawling up the stems and are likely to cause cross-pollination between different plants. 


\section{Discussion}

Leucas chinensis reproduce by means of cross pollination vectors playing very important role as a pollinator. If pollinators were not found plant capable of selfing also. In natural conditions $95 \%$ fruit set was observed. The flower architecture of Lamiaceae desined for pollinators. The bilabiate structure was evolved mainly for bees (Christian and Regine 2007). Many of the previous studies reveals that ant not a pollinator they were consumers of floral resources like petals, sepals, anther lobes and forages nectar and pollen. They were also attracted extrafloral resources. But here we directly documented the pollen loads on ants body parts and the movement of ant one flower to another cause the pollen transfer.

We were principally interested in knowing whether ants, which are often observed on the flowers of $L$. chinensis pollinate these flowers or whether they are nectar thieves. From observation we found that while looking for nectar, this species becomes coated with pollen grains and easily touches the stigma without destroying it. After some visitation we caught ant and the body parts of this insects dusted with pollen. The direct photographic documentation of ant behaviour also indicates that ant playing vital role as a pollen transfer.

\section{Reference}

[1]. Beker, R., Dafni, A., Eisikowitch, D. and Ravid, U., (1989). Volatail of two chemotypes of Majorana syriaca L. ( Labiate) as olfactory cues for the honeybee. Oecologia 79: 446-451.

[2]. Christian Westerkamp and Regine Claben-Bockoff 2007. Bilabiate Flowers: The Ultimate Response to Bees? Annals of Botany 100: 361-374.

[3]. Cruden, R.W. 1977. Pollen-ovule ratios, A conservation indicator of breeding system flowering plants. Evolution. 31: $32-46$.

[4]. Huck R.B (1992). Overview of pollination biology in the Lamiaceae. In R.M and I. Renolds (editors). Adavance in Labiate science, pp. 167-181. Royal Botanical Garden Kew.

[5]. Linskens, H.F. 1992. Sexual plant reproduction. 203-218 eds. M. Cresti and A. Tezzi

[6]. Springer-verlog, Berlin.

[7]. Reddi, C.S. \& N.S. Reddi. 1986. Pollen production in some anemophilous angiosperms.

[8]. Grana. 25:55-61.

[9]. Shivanna, K.R. \& N.S. Rangaswamy. 1992. Pollen biology: A laboratory manual. Narosa publishing House, New Delhi.

[10]. Shrishail K. Kulloli, Arun N. Chandore and Makarand M. Aitawade (2011). Nectar dynamics and pollination studies of three species of Lamiaceae. CURRENT SCIENCE, VOL. 100, NO. 4, 25. 